\title{
Attitudes of Turkish and Moroccan Belgians toward Redistribution and Government Responsibility: The Role of Perceived Discrimination, Generation, and Religious Involvement
}

\author{
Jolien Galle ${ }^{1}$, jolien.galle@kuleuven.be \\ Koen Abts ${ }^{2}$, k.abts@tilburguniversity.edu \\ Marc Swyngedouw ${ }^{1}$, marc.swyngedouw @kuleuven.be \\ Bart Meuleman ${ }^{1}$, bart.meuleman@ kuleuven.be
}

\footnotetext{
${ }^{1}$ Institute for Social and Political Opinion Research, Centre for Sociological Research, University of Leuven, Belgium

${ }^{2}$ Tilburg School of Social and Behavioral Sciences, Tilburg University, The Netherlands
}

\begin{abstract}
This article contributes to the debate about migration's impact on welfare state support by investigating the welfare opinions of migrants and their descendants. It examines whether experiences of group and individual discrimination explain the welfare attitudes of this group over and beyond classical predictors of self-interest and political ideology. Using survey data from Belgian citizens of Turkish and Moroccan descent, we show that stronger support for redistribution is associated with higher levels of perceived group discrimination, religious involvement, and belonging to the second generation. Preferences of government responsibility, however, are strongly determined by labor-market position and left-right ideology.
\end{abstract}




\section{INTRODUCTION}

Large-scale immigration is considered one of the important challenges facing Western welfare states and the extensive social services provided by their governments (Ervasti, Goul, and Ringdal 2012, Svallfors 2012). A central concern-also referred to as the progressive's dilemma-is that increased ethnic diversity caused by immigration might erode peoples' commitment to welfare state solidarity and redistribution in Europe (Alesina, Glaeser, and Sacerdote 2001, Goodhart 2004, Freeman 1986). Public-opinion research shows that Europeans regard immigration as a strain on the welfare state (Wright and Reeskens 2013), perceive immigrants as the group least deserving of social benefits (van Oorschot 2006), and think that immigrants benefit disproportionally from and contribute insufficiently to the welfare state (Reeskens and van Oorschot 2012, Van der Waal, De Koster, and Van Oorschot 2013). Although welfare attitudes and the immigration-welfare nexus have been studied extensively (see, for instance, Crepaz 2008, Van der Waal, De Koster, and Van Oorschot 2013, Eger and Breznau 2017, Mau and Burkhardt 2009), these topics have almost exclusively been investigated from the insider position of native-born citizens. Since an increasing proportion of the population in Western societies has a migration background and since this part of the population is more likely to become welfare dependent (Boeri et al. 2002), it has been argued that the perspective of migrants, both first and second generation, on the welfare state needs to be taken into account (Schmidt-Catran and Careja 2017).

Apart from qualitative research on the views of some specific groups of labor migrants toward the welfare state (Osipovic 2015, Timonen and Doyle 2009, Kremer 2016), only a few quantitative studies have explored migrants' attitudes toward government responsibility, redistribution, and welfare spending (Luttmer and Singhal 2011, Lubbers et al. 2018, Reeskens and van Oorschot 2015, Dancygier and Saunders 2006, Schmidt-Catran and Careja 2017). These studies tend to focus on two topics: (1) the existence of an opinion gap between migrants 
and native-born citizens, often referring to social mechanisms such as welfare magnetism (Borjas 1999) and self-selection (Chiswick 1999), and (2) the adjustment of migrants' attitudes to native-born citizens' attitudes over time, based on assimilation and socialization theories. Regarding an opinion gap, previous studies have shown that even though most immigrants hold somewhat stronger pro-welfare opinions than do native-born citizens, the differences are largely explained by immigrants' disadvantaged socioeconomic position and higher welfare dependence (Dancygier and Saunders 2006, Reeskens and van Oorschot 2015). Recently, the idea that the opinion gap is purely based on socioeconomic differences has been questioned by Lubbers et al. (2018), who find large differences in attitudes toward government spending between migrant groups and native-borns, even after accounting for their socioeconomic and ideological position. Studies on the adjustment of migrants' welfare opinions have found mixed results for the premise that immigrants gradually adjust their attitudes to those of the host population over time, depending on the data used and attitudinal dimensions investigated (Schmidt-Catran and Careja 2017, Luttmer and Singhal 2011, Reeskens and van Oorschot 2015).

Despite offering some valuable insights, existing research on migrants' attitudes toward redistribution and government responsibility has an important limitation because studies mostly use general population surveys, such as the European Social Survey (Luttmer and Singhal 2011, Reeskens and van Oorschot 2015) or General Social Survey (Luttmer 2001), that do not specifically target or oversample migrants. Although such studies allow comparisons with non-migrants and between countries, they aggregate minority groups with both varying cultural characteristics and different levels of welfare dependency into a single category or divide them into very broad categories, such as European and non-European migrants or firstand second-generation migrants (Dinesen 2012, Reeskens and van Oorschot 2015). As stated by Lubbers et al. $(2018,16)$, lumping migrants into a catch-all category misses a careful 
interpretation of migrant status, which cannot be reduced to a less favorable socio-economic status.

In this article, we argue that to understand the welfare opinions of first- and second-generation migrants, the particularities of their minority position in society must be considered, more specifically their experiences of intergroup inequality, social injustice, and ethnic discrimination. Therefore, this study tests whether perceived discrimination affects migrants' support for government responsibility and redistribution, in addition to testing the traditional determinants regarding structural position, self-interest, and left-right ideology. By testing explanatory models that go beyond the individual's position in society and by highlighting the importance of perceived group position, we contribute to the growing literature on migrants' welfare attitudes (Reeskens and van Oorschot 2015, Schmidt-Catran and Careja 2017, Lubbers et al. 2018). Instead of analyzing general population surveys, however, this study innovates by using the Belgian Ethnic Minorities Election Study 2014 (BEMES), which allows a focus on the specific case of Belgian citizens of Turkish and Moroccan descent.

\section{THEORY AND HYPOTHESES}

\section{Migrants' attitudes toward government responsibility and redistribution}

To date, individual-level predictors for migrants' welfare-state opinions stem predominantly from the literature on welfare attitudes within the general population and are based on explanations related to self-interest and political ideology (Jæger 2006). The self-interest approach posits that the welfare state is likely to be supported by people who receive welfare benefits or are at risk of becoming welfare dependent and by employees who profit professionally from an extensive welfare state (Blomberg et al. 2012, Gelissen 2000, Kangas 
1995). Research confirms that civil servants and people in more vulnerable categories - such as women, the unemployed, people with health problems, and those with low incomes - are more likely to favor government intervention, income redistribution, and welfare state policies (Hasenfeld and Rafferty 1989, Hoel and Knutsen 1989, Svallfors 1997, 1995, 2004, Svallfors and Taylor-Gooby 1999). The self-interest approach is complemented by indicators related to predispositions, values, and normative beliefs (Staerklé, Likki, and Scheidegger 2012, Sears et al. 1980, Mau 2003). Those identifying with the political left are more likely to favor government intervention and to have more positive attitudes toward the welfare state (Papadakis 1993, Jæger 2008, Papadakis and Bean 1993). Furthermore, people with strong feelings of economic insecurity are more in favor of social assistance (Burgoon and Dekker 2010), whereas citizens who believe that poverty's causes lie within the individual's control (Fong 2001) and who value a strong work ethic (Hasenfeld and Rafferty 1989) are less supportive of redistribution.

Based on these approaches, first- and second-generation migrants living in Europe, particularly those with origins in the post-war labor migration, can be expected to have positive attitudes toward government responsibility and redistribution, given their vulnerable socioeconomic positions (Heath, Rothon, and Kilpi 2008) and preference for left-of-center political parties (Sanders et al. 2014, Teney et al. 2010). Although existing studies confirm these expectations (Dancygier and Saunders 2006, Reeskens and van Oorschot 2015, Schmidt-Catran and Careja 2017), both self-interest - based on predictors such as experience of unemployment, income level, and work status - and left-right orientation have only a limited explanatory capacity with regard to migrants' welfare opinions (Reeskens and van Oorschot 2015, Lubbers et al. 2018). This finding suggests that to understand the determinants of attitudes toward government responsibility and redistribution of migrants and their descendants, insights into intergroup relations must be considered. More specifically, first- and second-generation migrants are 
prone to interpret their societal position in relation to the native society. Compared to other disadvantaged groups, migrants and their descendants are much more likely to perceive discriminatory treatment (Gelijkekansencentrum 2015), and these perceptions have been related to many other outcomes such as acculturation attitudes (Verkuyten and Nekuee 1999), life satisfaction (Verkuyten 2008), as well as identification and politicization (Fleischmann, Phalet, and Klein 2011). Therefore, traditional frameworks explaining welfare state attitudes should be expanded by taking into account perceptions of discrimination.

\section{Perceived discrimination and welfare attitudes}

Borrowing insights from relative deprivation theory and the literature concerning collective action (Van Zomeren, Postmes, and Spears 2008, Stouffer et al. 1949), we assume that the welfare attitudes of migrants and their descendants are related to their perceptions of intergroup inequality and injustice. A person's or group's feeling that compared with a relevant reference, they are unfairly deprived of desirable goods is referred to as relative deprivation (Stouffer et al. 1949, Vanneman and Pettigrew 1972, Merton and Rossi 1968). Relative deprivation is conceptualized as containing three elements: (1) People make comparisons with others, (2) they determine a disadvantage between themselves and others, and (3) this disadvantage is perceived as being unfair and causes feelings of resentment (Smith et al. 2012, Pettigrew 2016, Crosby 1976). In the case of ethnic minorities, such as most migrants and their descendants, relative deprivation largely coincides with perceived ethnic discrimination; that is, perceptions of differential treatment based on ethnic origin that unfairly disadvantages a person's own ethnic group (Quillian 2006, Kluegel and Bobo 2001). Although the notion of group relative deprivation emphasizes feelings of disadvantage in comparison with relevant reference groups, whereas perceived group discrimination focuses mainly on the act of unfair treatment, both 
concepts can be considered forms of perceived social injustice resulting from intergroup inequality (Van Zomeren, Postmes, and Spears 2008).

According to the collective action literature, minority group members who perceive group inequality are more likely to engage in political action to challenge this injustice and improve the group's conditions (Van Zomeren, Postmes, and Spears 2008, Dixon et al. 2010). Furthermore, group position theory predicts that perceptions of a threatened group position are likely to have a major influence on people's policy preferences (Bobo 1999, 463). As already mentioned, the welfare state is generally supported by people who have a vulnerable socioeconomic position because government intervention is seen by this group as a primary way to alter unfavorable market outcomes (Blomberg et al. 2012).We, thus, expect migrants who perceive themselves as disadvantaged to be more likely to be conscious of the welfare state's emancipatory facets and to view government intervention and redistributive policies as collective solutions to rectify the inequalities they experience. Under the condition that they perceive the national government as legitimate and that public institutions are not regarded as the cause of the actual injustice, migrants with strong feelings of relative deprivation or discrimination would therefore be more likely to favor government intervention and redistribution.

With regard to perceived injustice as a determinant of social protest, Runciman (1966) introduces an essential distinction between egoistic relative deprivation (a feeling of being unfairly disadvantaged as an individual) and fraternal relative deprivation (a feeling of being unfairly disadvantaged as a group). In terms of attitudinal and behavioral consequences, individual or egoistic relative deprivation is related to internal states, such as self-esteem, and to individual behavior (Verkuyten 1998). Group or fraternal relative deprivation, on the other hand, involves feelings of social injustice and is associated with intergroup attitudes, such as 
prejudice, social protest, and collective action aimed at structural changes in society (Walker and Smith 2002, Runciman 1966, Vanneman and Pettigrew 1972, Smith et al. 2012). As stated by Smith and Ortiz $(2002,111)$ :

When a disadvantage is defined in intergroup terms, people may be more concerned with outcome differences and less concerned with the implications for their personal self-image than when the same disadvantage is defined in interpersonal terms. Therefore they may be more willing to challenge the inequity. Not only might people feel less devastated by a disadvantage they interpret in intergroup terms, they may actually feel more empowered to deal with it.

Based on the evidence that fraternal deprivation is politically more potent (Runciman 1966, Sears et al. 1980, Vanneman and Pettigrew 1972), we hypothesize that a disadvantaged intergroup, rather than interpersonal, comparison is relevant for explaining welfare attitudes. More precisely, we expect that immigrant minorities, with higher levels of perceived group discrimination, are more likely to support redistribution (Hypothesis 1) and strong government responsibility (Hypothesis 2). Considering the relevance of the egocentric approach of perceived discrimination, we also account for the experience of individual discrimination but expect no - or a much smaller - effect of perceived individual discrimination on support for redistribution (Hypothesis 3) and government responsibility (Hypothesis 4).

\section{Generation and religious involvement}

In addition to perceptions of discrimination, this study also focuses on the effect of generation and religious involvement on the welfare attitudes of first- and second-generation migrants of Belgians of Turkish and Moroccan descent. Based on assimilation and social integration theories, it is predicted that immigrants adjust to their host country's cultural values, while the 
origin-country values are gradually lost (Gordon 1964, van Tubergen 2007, Maxwell 2010). Correspondingly, Reeskens and van Oorschot (2015) show that first- and second-generation migrants differ from each other with regard to their welfare opinions, and Schmidt-Catran and Careja (2017) find that migrants' preferences about the state's role, rooted in the culture of their origin country, are shaped by their contact with the host country's institutions. Considering the lower levels of welfare spending in Morocco and Turkey compared to Belgium, we therefore expect that second-generation migrants will be stronger supporters of redistribution (Hypothesis 5) and government responsibilities (Hypothesis 6) than firstgeneration migrants.

In terms of religion, a distinctive feature of the investigated population is that they are predominantly Muslim (Torrekens and Adam 2015). The relationship between religious involvement and welfare state support has not yet been studied among Muslim minorities, and existing European research - based on surveys mostly composed of populations with Protestant, Catholic, or secular sectors - presents mixed findings. Stegmueller et al. (2012) find that religious individuals are more opposed to income redistribution by the state, compared with secular individuals, while Ervasti (2012) and Lubbers et al. (2018) show that religiosity is positively related to support for government responsibility, social equality, and government spending on social assistance. In a non-Western context, Davis and Robinson (2006) found a positive association between religious orthodoxy and economic communitarianism; however, little is known about how Muslim minorities in European countries adapt their religious beliefs in relation to the Western welfare state (Dean and Khan 1997, 204). According to Islamic teachings, both the state's responsibility to ensure a basic standard of living for all citizens and the reduction of the gap between rich and poor are of great importance (Dean and Khan 1997). The moral principle that embodies Islamic commitment to welfare and social justice can be traced back to the concept of Zakat, which is a religious tax on property with the function of 
avoiding wealth accumulation and reducing the gap between rich and poor (Dean and Khan 1997, Ahmad 1991). The literature on an Islamic vision of a just socio-economic order therefore leads us to expect a positive relation between religious involvement and support for redistribution (Hypothesis 7) and government responsibilities (Hypothesis 8) among the mostly Muslim population in this study.

\section{The case of Turkish and Moroccan minorities in Belgium}

Turkish and Moroccan minorities in Belgium have their origins in labor migrations of the 1960s and 1970s and subsequent family reunification and marriage migration (Surkyn and Reniers 1996). As official statistics on ethnicity are lacking in Belgium, the exact proportion of the population with a foreign background cannot be calculated. Nonetheless, it is estimated that about 2 percent of the Belgian population are of Turkish descent (Schoonvaere 2013) and 3.8 percent of Moroccan descent (Schoonvaere 2014). The majority of these groups have obtained Belgian citizenship and formally have the same social rights as citizens of native descent (Schoonvaere 2014, Gsir, Mandin, and Mescoli 2015, Schoonvaere 2013). However, this formal equality does not translate into an equal social position, given that Turkish and Moroccan minorities are among the lowest in the ethnic hierarchy in Western societies (Hagendoorn 1995). Compared with Belgians that have native-born parents, Turkish and Moroccan minorities attain lower education levels (Timmerman, Vanderwaeren, and Crul 2003), are five times more likely to be unemployed (Martens and Verhoeven 2006, Van den Broucke et al. 2015), and are overrepresented in the labor market's secondary sectors (Timmerman, Vanderwaeren, and Crul 2003). In addition, more than half the population of Turkish or Moroccan descent has an income below the poverty line, compared with 10 percent of Belgians with a native background (Van Robaeys and Perrin 2007). In sum, the combination of being an insider in the legal sense, while remaining an outsider in reality, creates a high 
likelihood of perceived discrimination among these groups (Alanya et al. 2017). This dual position makes it relevant to investigate the relationship between perceived discrimination and welfare attitudes among this population.

\section{DATA AND METHODS}

\section{Data}

We use data from the Belgian Ethnic Minorities Election Study 2014 (BEMES), a face-to-face survey among first- and second-generation Belgian citizens of Turkish and Moroccan descent aged at least 18. The survey was conducted in two Belgian cities: Liège, located in the Frenchspeaking part of Belgium (Wallonia), and Antwerp, located in the Dutch-speaking part (Flanders) (Swyngedouw et al. 2015). Computer-assisted personal interviews were conducted at respondents' homes by trained interviewers in Dutch or French. Since the sample only concerns respondents with sufficient knowledge of Dutch or French, the first generation is likely underrepresented, while relatively well-integrated respondents may be overrepresented. Considering the difficulties related to surveying migrants and ethnic minorities (Font and Méndez 2013), an overall response rate of 34.9 percent was obtained. More specifically, the BEMES data include 878 respondents from four groups randomly selected from the cities' population registers: Belgians of Moroccan descent in Antwerp $(\mathrm{N}=243$; response rate $39.1 \%)$, Belgians of Turkish descent in Antwerp ( $\mathrm{N}=239$; response rate 37.2\%), Belgians of Moroccan descent in Liège $(\mathrm{N}=188$; response rate $25.8 \%)$, and Belgians of Turkish descent in Liège ( $\mathrm{N}$ $=208$; response rate 39.9\%). Since the elderly and people of Moroccan descent are somewhat underrepresented, post-stratification weight coefficients based on age, gender, city of residence, and ethnic background were applied. 


\section{Measurements}

\section{Dependent variables}

Attitude toward redistribution is operationalized by a scale based on three 5-point Likert items regarding the reduction of class differences and income inequality. Attitude toward government responsibility is operationalized by three 11-point scales on the government's responsibility for providing pensions, health care, and a reasonable standard of living for the unemployed. Confirmatory Factor Analysis showed that a two-factor model - attitude toward government responsibility and attitude toward redistribution - fits the data better $\left(\chi^{2}=44.061\right.$; $\mathrm{df}=8$; RMSEA $=0.072 ; \mathrm{CFI}=0.942 ; \mathrm{TLI}=0.891)$ than a one-factor model $\left(\chi^{2}=288.396 ; \mathrm{df}=9\right.$; RMSEA $=0.188 ; \mathrm{CFI}=0.552 ; \mathrm{TLI}=0.253)$. The standardized correlation between the two constructs is $0.16(\mathrm{p}=0.004)$, which is relatively weak and might imply the need for different explanatory models.

\section{Independent variables}

We include the following indicators with regard to socio-structural position, self-interest, and political ideology. Gender is operationalized by a dummy variable with the value 1 for women and 0 for men. A dummy variable with the value 1 for Turkish descent and 0 for Moroccan descent indicates respondents' migration background. City of residence is operationalized in a similar manner, with the value 0 for respondents living in Antwerp and 1 for respondents living in Liège. Age is coded into four categories: 18-24 years old, 25-34 years old, 35-44 years old, and 45-93 years old. Respondents' level of education is measured with four categories: Less than lower-secondary education, lower-secondary education, higher-secondary education, and tertiary education. Respondents' position in the labor market is taken into account by a variable that distinguishes between respondents not active in the labor market, blue-collar workers, and 
white-collar workers. Economic insecurity is measured by a scale of three items asking respondents how often they worry about having financial difficulties or maintaining their socioeconomic position in the future. To measure the left-right identification, respondents had to place themselves on a scale from 0 (left) to 10 (right).

The generation to which respondents belong is operationalized into three categories: Firstgeneration migrants are defined as people who were born abroad and migrated to Belgium after the age of 15 , the intermediate generation - or generation 1.5 - refers to people who were born outside Belgium and migrated before the age of 15 , and the second generation refers to respondents who were born in Belgium, with one or both parents having been born in Morocco or Turkey (Heath et al. 2013, Rumbaut and Ima 1987). To operationalize religious involvement, a distinction is made between respondents who reported not being Muslim, non-strictly practicing Muslims, and strictly practicing Muslims. To define this last category, we differentiate between male and female respondents (Loewenthal, MacLeod, and Cinnirella 2002). If a female respondent reported having always fasted during the last Ramadan and praying at least five times per day, she was categorized as a strictly practicing Muslim. For male respondents in this category, it was additionally required that they reported visiting a mosque weekly or more. The category of others relates to a small and heterogeneous group containing atheists, Catholics, and Yezidis.

Finally, we introduce two measures of perceived discrimination to explain the welfare attitudes of these immigrant minorities. Perceived group discrimination is measured by four 5-point Likert items referring to perceived differential treatment of respondents' own ethnic group in times of economic crisis, by the government, by city services, and at the social assistance agency. Confirmatory Factor Analysis showed that the items are reliable and valid measurements $\left(\chi^{2}=3.070 ; \mathrm{df}=2 ; \mathrm{RMSEA}=0.025 ; \mathrm{CFI}=0.999 ; \mathrm{TLI}=0.998\right)$. Additionally, 
we include a dummy variable with score 1 for respondents who reported having personally experienced hostility or unfair treatment because of their background or descent during the last five years.

To test our hypotheses, we used structural equation modeling (SEM) estimated in Mplus version 7.1 (Muthén and Muthén 1998-2012). As suggested by Kline (2011), we used a twostep approach: we first tested the measurement models of support for redistribution and government responsibility and perceived group discrimination and then tested the structural model with the two welfare attitudes as dependent variables. The exact question wordings and standardized factor loadings of the latent variables can be found in Table 1. Descriptive statistics of the observed variables are shown in the online Appendix.

\section{RESULTS}

Based on the descriptive statistics in Table 1, it appears that the surveyed Belgians of Turkish and Moroccan descent are very supportive of government responsibility and redistribution. The mean scores show that overall, respondents agreed with the reduction of class differences $(\mathrm{M}$ $=3.99 ; \mathrm{SD}=1.02)$ and government redistribution of income differentials $(\mathrm{M}=3.77 ; \mathrm{SD}=$ 1.02), while they disagree with the statement that differences between high and low incomes should stay as they are $(\mathrm{M}=2.22 ; \mathrm{SD}=0.99)$. In general, on an 11-point scale, respondents preferred very high levels of government responsibility in the provision of pensions $(M=8.75$; $\mathrm{SD}=1.67)$, health care $(\mathrm{M}=9.03 ; \mathrm{SD}=1.48)$, and a reasonable standard of living for the unemployed $(\mathrm{M}=7.71 ; \mathrm{SD}=2.2)$. On average, respondents agreed with the statements that people like them are being systematically neglected $(\mathrm{M}=3.05 ; \mathrm{SD}=1.03)$ and the first victims in times of crisis $(\mathrm{M}=3.12 ; \mathrm{SD}=1.06)$. They also reported unequal treatment of their ethnic 
group by the government $(\mathrm{M}=2.95 ; \mathrm{SD}=1.05)$ and at the social assistance agency $(\mathrm{M}=3.00$; $\mathrm{SD}=0.96)$

[Table 1 about here]

Table 2 presents the results of the analyses explaining the welfare attitudes of Turkish and Moroccan Belgians. We report fully standardized parameter estimates (expressed in how many standard deviations the dependent variable changes when the predictor increased by one standard deviation). As a result, we can compare the effect size of the different predictors and for the two dependent variables. Considering the predictors referring to social position, religious involvement, and generation, we are able to explain 14.9 percent (redistribution) and 13.0 percent (government responsibility) of variation in the welfare attitudes of Turkish and Moroccan Belgians. Adding perceived discrimination in the second step increases the explained variances to, respectively, 19.4 percent and 15.6 percent.

[Table 2 about here]

Table 2 shows that the structural characteristics mostly used in research among the general population are also relevant for explaining the welfare attitudes of Belgians of Turkish and Moroccan descent. Controlling for generation, it appears that the youngest group of respondents is the least likely to support redistribution. With regard to the self-interest approach, our study shows mixed findings. On the one hand, there is a positive effect of being inactive in the labor market, rather than being a blue-collar worker, on attitudes toward government responsibility $(\beta=0.187 ; \mathrm{p}=0.005)$ and a negative effect of educational level on support for redistribution. On the other hand, the fact that white-collar workers also strongly support government responsibility contradicts the idea of calculated self-interest. Nevertheless, there is a strong positive effect of economic insecurity on both the demand for redistribution $(\beta=0.166 ; p=0.002)$ and government intervention $(\beta=0.167 ; p=0.000)$. This finding 
illustrates the importance of considering not only structural characteristics but also people's everyday life experiences when explaining their welfare attitudes. Turning to another factor drawn from the general welfare attitudes literature, our results show that left-right identification is one of the strongest predictors of Turkish and Moroccan Belgians' opinion on government responsibility $(\beta=-0.209 ; p=0.000)$, with leftist people being more supportive. Interestingly, there is no significant effect of political ideology on attitudes toward redistribution $(\beta=-0.019$; $\mathrm{p}=0.725)$

Overall, it stands out that the predictors of the two welfare attitudes are quite divergent. While both generation and religious involvement are relevant for Turkish and Moroccan Belgians' support for redistribution, they are unrelated to their opinions about government responsibilities. Contrary to our expectations, there are no generational differences in opinions about government responsibility (H6), whereas Turkish and Moroccan Belgians belonging to the second generation are more in favor of redistribution than is the first generation $(\mathrm{H} 5 ; \beta=$ 0.173; $\mathrm{p}=0.037)$. Regarding religious involvement, our analysis shows no effect on attitudes toward government responsibilities (H8) but confirms that compared with non-strictly practicing Muslims, strictly practicing Muslims are much more in favor of redistribution (H7; $\beta=0.219 ; \mathrm{p}=0.000)$. This finding is in line with religiosity's generally positive effect on welfare attitudes, as found by Ervasti (2012) and our prediction based on the Islamic vision of a just socio-economic order with a strong emphasis on reducing the gap between rich and poor (Dean and Khan 1997).

With regard to perceived discrimination, the results only partly confirm our hypotheses. As expected, Turkish and Moroccan Belgians with higher levels of perceived group discrimination are more likely to favor redistribution. However, while the effect is strong and significant for attitudes toward redistribution $(\mathrm{H} 1 ; \beta=0.176 ; \mathrm{p}=0.000)$, perceived group discrimination is 
not significantly related $(\mathrm{H} 2 ; \beta=0.033 ; \mathrm{p}=0.432)$ to attitudes toward government responsibility. Interestingly, the government's responsibility to ensure social provisions is presumably more interpreted in left-right terms (i.e., the desired degree of direct government regulation and intervention either alongside or instead of market mechanisms) and less understood in terms of actual intergroup relations and the perceived injustice involved. It is noteworthy that perceptions of group discrimination, even after controlling for economic insecurity and perceived individual discrimination, are still relevant for explaining Turkish and Moroccan Belgians' support for redistribution. Perceptions of group inequality thus matter, as do measures of vulnerability at the personal level.

Lastly, while the absence of a significant effect of perceived individual discrimination on attitudes toward redistribution $(\mathrm{H} 3 ; \beta=-0.105, \mathrm{p}=0.077)$ is in line with our expectations, our analyses show somewhat surprisingly that perceived individual discrimination is negatively related to support for government responsibility $(H 4 ; \beta=-0.131 ; p=0.021)$. Similar to studies on well-being (Molero et al. 2011) and self-esteem (Bourguignon et al. 2006), we find that group and individual discrimination appear to have opposing effects on Turkish and Moroccan Belgians' welfare opinions. Perceiving group discrimination and attributing this deprivation to an external or structural cause induces collective action (Dixon et al. 2010) and, as our study shows, a stronger demand for the redistribution of income inequalities. Perceived individual discrimination, however, is directly related to evaluations of the self and may result in selfblame (Bourguignon et al. 2006), though not in a demand for redistribution or government intervention. Even more, our analysis suggests a negative effect of perceived individual discrimination on support for government responsibility among Belgians of Turkish and Moroccan descent. Hypothetically, it might be that people who have personally experienced unfair treatment have lower levels of institutional trust and therefore consider the government not to be a legitimate authority for reducing experienced inequalities. More research is required, 
however, to examine whether the negative effect of perceived discrimination on support for government responsibility is caused by decreased trust in government institutions.

\section{CONCLUSIONS}

In debates about the relation between migration and the welfare state, migrants tend to be considered objects of discussion rather than subjects with their own opinions (Kremer 2016). The few quantitative studies that try to explain the welfare attitudes of migrants and their descendants are mostly limited to indicators of self-interest and political ideology (Reeskens and van Oorschot 2015, Lubbers et al. 2018, Schmidt-Catran and Careja 2017, Dancygier and Saunders 2006). The analysis presented here adds substantially to our understanding of support for redistribution and government responsibility among first- and second-generation migrants. Taking into account the classic predictors based on structural position and ideology, it innovates by introducing perceptions of unequal treatment, both at the individual and group level, and by investigating potential divides among migrants along generational lines and religious involvement.

First, our study indicates that Turkish and Moroccan Belgians' attitudes toward government responsibility are shaped by their labor-market position, economic insecurity, and left-right self-placement, implying that their opinions fit into the conventional left-right ideological divisions between a free market and regulated market poles. Their attitudes toward government responsibility are not related to perceived group discrimination, suggesting that the extent to which the government should be responsible for social welfare provision is not framed in intergroup inequalities. However, contrary to our expectations, perceived individual discrimination appears to be negatively related to support for government responsibility. Based on studies looking at the consequences of individual experiences of discrimination among minority group members (Branscombe, Schmitt, and Harvey 1999, Jasinskaja - Lahti, 
Liebkind, and Solheim 2009, Schmitt and Branscombe 2002, Verkuyten 2005), we propose that the negative effect of perceived individual discrimination might be related to diminished institutional trust and identification with the host country. However, additional studies including these measures are required to test this post-hoc argumentation.

Second, our study shows that besides educational level and economic insecurity, support for redistribution is related to religious involvement, generation, and perceived group discrimination. In this sense, Turkish and Moroccan Belgians' egalitarian attitudes seem to be less connected to self-interest and the traditional ideological left-right divide and more structured by cultural capital and actual intergroup relations and the perceived injustice involved. The feeling of being unfairly deprived as a group results in a greater willingness to challenge income inequality. According to this logic, first- and second-generation migrants' attitudes toward redistribution originate - at least partially - from the perception that their proprietary claims over certain rights and resources are not valorized by the native society. In a similar vein, our results illustrate that the study of migrants' welfare attitudes is meaningless without reference to the specific context of group positions and institutional discrimination.

Third, our work suggests that predictors for attitudes toward government responsibility and redistribution are quite divergent. This finding is significant, since the two welfare attitudes are often considered to be strongly interrelated or even equivalent (Svallfors 1997, Blekesaune and Quadagno 2003). These differences in predictors point to the distinction, made by Borre and Scarbrough (1995), between welfare policies aimed at socioeconomic security and welfare policies aimed at socioeconomic equality. We show that among Belgians of Turkish or Moroccan descent, support for redistribution is associated with religious involvement and perceived group discrimination, while preferences regarding government responsibility are shaped by labor-market position and left-right placement. Our study thus highlights the 
importance of group-related social experiences and predispositions for attitudes toward welfare policies aimed at socioeconomic equality (Roller 1995) and the importance of social class and left-right placement for attitudes toward welfare policies aimed at socioeconomic security (Pettersen 1995). This finding reaffirms the need to distinguish between different types of welfare attitudes and to further explore additional explanatory variables. It also suggests that we cannot assume that support for government intervention follows self-evidently from egalitarianism, and vice versa.

Fourth and finally, we assert that it is essential to recognize different fractions within the nonnative population, as our findings suggest that both generation and religious involvement crosscut ethnic divisions. While there is no effect based on origin country, our study shows that second-generation migrants are more in favor of redistribution than are first-generation migrants, while strictly practicing Muslims are the strongest supporters of redistribution. In this regard, we innovate by exploring the role of religious involvement among a mostly Muslim population, demonstrating that Muslim minorities' strong religious involvement does not necessarily obstruct their welfare state solidarity within Belgian society.

Focusing on well-defined minority groups (i.e., Turkish and Moroccan Belgians) allowed us to overcome some of the difficulties of existing studies caused by aggregating very different minority groups into a single category (Lubbers et al. 2018). This design helped shed light on the wider context of the welfare attitudes of post-war labor migrants and their descendants that have settled in Western Europe. By considering the particularities of migrants' position in the native society and the perceived unequal treatment that is involved, our study uncovered the complex nature of migrants' attitudes toward the welfare state, something which cannot be captured by the determinants used in the literature among the general population. As such we contribute to the understanding of the welfare opinions of migrants and their descendants, 
which is highly relevant for policy makers in Europe, where societies are currently debating the impact of migration and increased diversity on support for welfare state solidarity (Larsen 2011, Kymlicka and Banting 2006). Although this study focuses on the role of perceived discrimination for the welfare attitudes of first- and second-generation migrants, its insights may also be relevant for explaining the opinions of other disadvantaged groups.

Nonetheless, this study has limitations related to the investigated population and the data used. First, people of Turkish and Moroccan descent form a specific and visible minority group within Belgian society. Therefore, it remains to be investigated whether perceptions of a disadvantaged group position have the same relevance for welfare opinions in other contexts where migrants form less identifiable minority groups. The fact that this study concerns only respondents with Belgian citizenship and sufficient knowledge of Dutch or French can be considered a second limitation. Given that citizenship and length of stay in the host country are relevant factors in the socialization of migrants' welfare attitudes (Reeskens and van Oorschot 2015, Luttmer and Singhal 2011), additional research is necessary to understand the predictors of welfare opinions for migrants with a more recent and temporary settlement. Furthermore, since this study is limited to two Belgian cities, it remains to be investigated whether the current findings can be generalized toward the entire community of immigrant minorities. Finally, this study analyzed rather generic welfare attitudes, showing that Turkish and Moroccan Belgians are overall strong welfare-state supporters. However, it has been revealed that migrants' preferences regarding government spending differ between welfare domains (Lubbers et al. 2018), and it is possible that, due to their dual position, minority group members combine an overall positive attitude toward the welfare state's general principles with a critique of its functioning. Our main suggestion for future research is therefore to investigate additional welfare attitudes among migrants, such as perceived welfare state consequences (van Oorschot 2010) and deservingness perceptions (van Oorschot 2000). 


\section{REFERENCES}

Ahmad, Ziauddin. 1991. Islam, Poverty, and Income Distribution, Islamic Economic Series. Leicester, UK: The Islamic Foundation.

Alanya, Ahu, Marc Swyngedouw, Veronique Vandezande, and Karen Phalet. 2017. "Close Encounters: Minority and Majority Perceptions of Discrimination and Intergroup Relations in Antwerp, Belgium." International Migration Review 51 (1):191-217. doi: 10.1111/imre.12203.

Alesina, Alberto, Edward Glaeser, and Bruce Sacerdote. 2001. "Why Doesn't the United States Have a European-Style Welfare State?" Brookings Papers on Economic Activity 2001 (2):187-254. doi: 10.2307/1209137.

Blekesaune, Morten, and Jill Quadagno. 2003. "Public Attitudes toward Welfare State Policies: A Comparative Analysis of 24 Nations." European Sociological Review 19 (5):415-427. doi: 10.1093/esr/19.5.415.

Blomberg, H., J. Kallio, Olli E. Kangas, C. Kroll, and M. Niemelä. 2012. "Attitudes among high-risk groups." In Contested Welfare States. Welfare attitudes in Europe and beyond., edited by Stefan Svallfors, 58-80. Stanford, California: Stanford Press.

Bobo, Lawrence. 1999. "Prejudice as group position: Microfoundations of a sociological approach to racism and race relations." Journal of Social Issues 55 (3):445-472.

Boeri, T., G.H. Hanson, B. McCormick, and H. Brücker, eds. 2002. Immigration Policy and the Welfare System: A Report for the Fondazione Rodolfo Debenedetti. Edited by Fondazione Rodolfo Debenedetti: Oxford University Press.

Borjas, George J. 1999. "Immigration and Welfare Magnets." Journal of Labor Economics 17 (4):607-637. doi: 10.1086/209933.

Borre, Ole, and Elinor Scarbrough, eds. 1995. The Scope of Government, Beliefs in Government: Oxford University Press.

Bourguignon, David, Eleonore Seron, Vincent Yzerbyt, and Ginette Herman. 2006. "Perceived group and personal discrimination: differential effects on personal selfesteem." European Journal of Social Psychology 36 (5):773-789. doi: 10.1002/ejsp.326.

Branscombe, Nyla R, Michael T Schmitt, and Richard D Harvey. 1999. "Perceiving pervasive discrimination among African Americans: Implications for group identification and well-being." Journal of personality and social psychology 77 (1):135-149.

Burgoon, Brian, and Fabian Dekker. 2010. "Flexible employment, economic insecurity and social policy preferences in Europe." Journal of European Social Policy 20 (2):126141. doi: 10.1177/0958928709358789. 
Chiswick, Barry R. 1999. "Are Immigrants Favorably Self-Selected?" The American Economic Review 89 (2):181-185. doi: 10.2307/117103.

Crepaz, Markus M. L. 2008. Trust Beyond Borders: Immigration, the Welfare State, and Identity in Modern Societies: University of Michigan Press.

Crosby, Faye J. 1976. "A model of egoistical relative deprivation." Psychological Review 83 (2):85-113.

Dancygier, Rafaela, and Elizabeth N. Saunders. 2006. "A New Electorate? Comparing Preferences and Partisanship between Immigrants and Natives." American Journal of Political Science 50 (4):962-981. doi: 10.1111/j.1540-5907.2006.00227.x.

Davis, Nancy J., and Robert V. Robinson. 2006. "The Egalitarian Face of Islamic Orthodoxy: Support for Islamic Law and Economic Justice in Seven Muslim-Majority Nations." American Sociological Review 71 (2):167-190. doi: 10.1177/000312240607100201.

Dean, Hartley, and Zafar Khan. 1997. "Muslim Perspectives on Welfare." Journal of Social Policy 26 (2):193-209. doi: 10.1017/S0047279497004972.

Dinesen, Peter Thisted. 2012. "Does Generalized (Dis)Trust Travel? Examining the Impact of Cultural Heritage and Destination-Country Environment on Trust of Immigrants." Political Psychology 33 (4):495-511. doi: 10.1111/j.1467-9221.2012.00886.x.

Dixon, John, Kevin Durrheim, Colin Tredoux, Linda Tropp, Beverley Clack, and Liberty Eaton. 2010. "A Paradox of Integration? Interracial Contact, Prejudice Reduction, and Perceptions of Racial Discrimination." Journal of Social Issues 66 (2):401-416. doi: 10.1111/j.1540-4560.2010.01652.x.

Eger, Maureen A, and Nate Breznau. 2017. "Immigration and the welfare state: A crossregional analysis of European welfare attitudes." International Journal of Comparative Sociology 58 (5):440-463. doi: 10.1177/0020715217690796.

Ervasti, H. 2012. "Is there a religious factor involved in support for the welfare state in Europe?" In The Future of the Welfare State: Social Policy Attitudes and Social Capital in Europe, edited by H. Ervasti, J. Goul and K. Ringdal, 214-229. Edward Elgar Publishing.

Ervasti, H., J. Goul, and K. Ringdal. 2012. The Future of the Welfare State: Social Policy Attitudes and Social Capital in Europe: Edward Elgar Publishing.

Fleischmann, Fenella, Karen Phalet, and Olivier Klein. 2011. "Religious identification and politicization in the face of discrimination: Support for political Islam and political action among the Turkish and Moroccan second generation in Europe." British Journal of Social Psychology 50 (4):628-648. doi: 10.1111/j.20448309.2011.02072.x.

Fong, Christina. 2001. "Social preferences, self-interest, and the demand for redistribution." Journal of Public Economics 82 (2):225-246. doi: 10.1016/S0047-2727(00)00141-9. 
Font, Joan, and Mónica Méndez. 2013. Surveying Ethnic Minorities and Immigrant Populations : Methodological Challenges and Research Strategies. Amsterdam: Amsterdam University Press.

Freeman, Gary P. 1986. "Migration and the Political Economy of the Welfare State." Annals of the American Academy of Political and Social Science 485:51-63. doi: $10.2307 / 1045440$.

Gelijkekansencentrum, Interfederaal. 2015. Jaarverslag 2014: Een keerpunt voor het Centrum. Brussel.

Gelissen, J. 2000. "Popular support for institutionalised solidarity: a comparison between European welfare states." International Journal of Social Welfare 9 (4):285-300. doi: 10.1111/1468-2397.00140.

Goodhart, David. 2004. "Too diverse?" Prospect Magazine, February, 20th. http://www.prospect-magazine.co.uk/article_details.php?id=5835.

Gordon, Milton M. 1964. Assimilation in American Life: The Role of Race, Religion and National Origins. New York: Oxford University Press.

Gsir, Sonia, Jérémy Mandin, and Elsa Mescoli. 2015. Corridor report on Belgium - Moroccan and Turkish immigration in Belgium. San Domenico di Fiesole (FI): Robert Shuman Centre for Advanced Studies.

Hagendoorn, Louk. 1995. "Intergroup Biases in Multiple Group Systems: The Perception of Ethnic Hierarchies." European Review of Social Psychology 6 (1):199-228. doi: 10.1080/14792779443000058.

Hasenfeld, Yeheskel, and Jane A. Rafferty. 1989. "The Determinants of Public Attitudes Toward the Welfare State." Social Forces 67 (4):1027-1048.

Heath, Anthony F., Stephen D. Fisher, Gemma Rosenblatt, David Sanders, and Maria Sobolewski. 2013. The Political Integration of Ethnic Minorities in Britain. Oxford: Oxford University Press.

Heath, Anthony F., Catherine Rothon, and Elina Kilpi. 2008. "The Second Generation in Western Europe: Education, Unemployment, and Occupational Attainment." Annual Review of Sociology 34 (1):211-235. doi: 10.1146/annurev.soc.34.040507.134728.

Hoel, Marit, and Oddbjorn Knutsen. 1989. "Social class, gender, and sector employment as political cleavages in Scandinavia." Acta Sociologica 32 (2):181-201.

Jæger, Mads Meier. 2006. "What Makes People Support Public Responsibility for Welfare Provision: Self-interest or Political Ideology?A Longitudinal Approach." Acta Sociologica 49 (3):321-338. doi: 10.1177/0001699306067718.

Jæger, Mads Meier. 2008. "Does Left-Right Orientation have a Causal Effect on Support for Redistribution? Causal Analysis with Cross-sectional Data Using Instrumental Variables." International Journal of Public Opinion Research 20 (3):363-374. doi: 10.1093/ijpor/edn030. 
Jasinskaja - Lahti, Inga, Karmela Liebkind, and Erling Solheim. 2009. "To Identify or Not

To Identify? National Disidentification as an Alternative Reaction to Perceived Ethnic Discrimination." Applied Psychology 58 (1):105-128. doi: 10.1111/j.14640597.2008.00384.x.

Kangas, Olli E. 1995. "Attitudes on Means-Tested Social Benefits in Finland." Acta Sociologica 38 (4):299-310.

Kline, Rex B. 2011. Principles and Practice of Structural Equation Modeling. Edited by David A. Kenny. 3 ed, Methodology in the Social Sciences. New York: The Guilford Press.

Kluegel, James R., and Lawrence Bobo. 2001. "Perceived Group Discrimination and Policy Attitudes: The Sources and Consequences of the Race and Gender." In Urban Inequality: Evidence from Four Cities, edited by A. O'Connor, C. Tilly and Lawrence Bobo, 163-198. New York: Russell Sage Foundation.

Kremer, Monique. 2016. "Earned Citizenship: Labour Migrants' Views on the Welfare State." Journal of Social Policy 45 (3):395-415. doi: 10.1017/S0047279416000088.

Kymlicka, Will, and Keith Banting. 2006. "Immigration, multiculturalism, and the welfare state." Ethics and International Affairs 20 (3):281-304.

Larsen, Christian Albrekt. 2011. "Ethnic Heterogeneity and Public Support for Welfare: Is the American Experience Replicated in Britain, Sweden and Denmark?" Scandinavian Political Studies 34 (4):332-353. doi: 10.1111/j.14679477.2011.00276.x.

Loewenthal, Kate Miriam, Andrew K. MacLeod, and Marco Cinnirella. 2002. "Are women more religious than men? Gender differences in religious activity among different religious groups in the UK." Personality and Individual Differences 32 (1):133-139. doi: 10.1016/S0191-8869(01)00011-3.

Lubbers, Marcel, Claudia Diehl, Theresa Kuhn, and Christian Albrekt Larsen. 2018. "Migrants' support for welfare state spending in Denmark, Germany, and the Netherlands." Social Policy \& Administration. doi: 10.1111/spol.12404.

Luttmer, Erzo F. P. 2001. "Group Loyalty and the Taste for Redistribution." Journal of Political Economy 109 (3):500-528. doi: 10.1086/321019.

Luttmer, Erzo F. P., and Monica Singhal. 2011. "Culture, Context, and the Taste for Redistribution." American Economic Journal: Economic Policy 3 (1):157-79. doi: 10.1257/pol.3.1.157.

Martens, Albert, and Hans Verhoeven. 2006. "Etnische minderheden op de arbeidsmarkt in België." In Immigratie en integratie anders denken: een Belgisch interuniversitair initiatief, edited by Bichara Khader, Marco Martiniello, Andrea Rea and Christiane Timmerman, 265-290. Brussel: Bruylant. 
Mau, Steffen. 2003. The Moral Economy of Welfare States. Britain and Germany compared. Edited by Martin Rhodes and Maurizio Ferrera. Vol. 1, Routledge/EUI Studies in the Political Economy of Welfare. Oxon, New York: Routledge.

Mau, Steffen, and Christoph Burkhardt. 2009. "Migration and welfare state solidarity in Western Europe." Journal of European Social Policy 19 (3):213-229. doi: $10.1177 / 0958928709104737$.

Maxwell, Rahsaan. 2010. "Evaluating Migrant Integration: Political Attitudes Across Generations in Europe1." International Migration Review 44 (1):25-52. doi: 10.1111/j.1747-7379.2009.00797.x.

Merton, Robert K, and Alice S Rossi. 1968. "Contributions to the theory of reference group behavior." In Social theory and social structure, edited by Robert K Merton, 279-334. New York: The Free Press.

Molero, Fernando, María J. Fuster, Jolanda Jetten, and Juan A. Moriano. 2011. "Living With HIV/AIDS: A Psychosocial Perspective on Coping With Prejudice and Discrimination." Journal of Applied Social Psychology 41 (3):609-626. doi: 10.1111/j.1559-1816.2011.00729.x.

Muthén, L.K. , and B.O. Muthén. 1998-2012. Mplus User's Guide. Seventh Edition. . Los Angeles, CA: Muthén \& Muthén.

Osipovic, Dorota. 2015. "Conceptualisations of Welfare Deservingness by Polish Migrants in the UK." Journal of Social Policy 44 (04):729-746. doi: 10.1017/S0047279415000215.

Papadakis, Elim. 1993. "Class Interests, Class Politics and Welfare State Regime." The British Journal of Sociology 44 (2):249-270. doi: 10.2307/591219.

Papadakis, Elim, and Clive Bean. 1993. "Popular Support for the Welfare State: A Comparison Between Institutional Regimes." Journal of Public Policy 13 (03):227254. doi: doi:10.1017/S0143814X00001057.

Pettersen, Per Arnt. 1995. "The Welfare State: The Security Dimension." In The Scope of Government, edited by Ole Borre and Elinor Scarbrough, 198-233. Oxford University Press.

Pettigrew, Thomas F. 2016. "In Pursuit of Three Theories: Authoritarianism, Relative Deprivation, and Intergroup Contact." Annual Review of Psychology 67 (1):1-21. doi: doi:10.1146/annurev-psych-122414-033327.

Quillian, Lincoln. 2006. "New Approaches to Understanding Racial Prejudice and Discrimination." Annual Review of Sociology 32:299-328. doi: 10.2307/29737741.

Reeskens, Tim, and Wim van Oorschot. 2012. "Disentangling the 'New Liberal Dilemma': On the relation between general welfare redistribution preferences and welfare chauvinism." International Journal of Comparative Sociology 53 (2):120-139. doi: $10.1177 / 0020715212451987$. 
Reeskens, Tim, and Wim van Oorschot. 2015. "Immigrants' Attitudes towards Welfare Redistribution. An Exploration of Role of Government Preferences among Immigrants and Natives across 18 European Welfare States." European Sociological Review 31 (4):433-445. doi: 10.1093/esr/jcv003.

Roller, Edeltraud. 1995. "The Welfare State: The Equality Dimension." In The Scope of Government, edited by Ole Borre and Elinor Scarbrough, 165-197. Oxford University Press.

Rumbaut, Ruben G., and Kenji Ima. 1987. "The Adaptation of Southeast Asian Refugee Youth: A Comparative Study." Final Report, Washington, D.C., U.S. Office of Refugee Resettlement, 1988.

Runciman, W. G. 1966. Relative Deprivation and Social Justice: A Study of Attitudes to Social Inequality in Twentieth Century England London: Penguin.

Sanders, David, Anthony Heath, Stephen Fisher, and Maria Sobolewska. 2014. "The Calculus of Ethnic Minority Voting in Britain." Political Studies 62 (2):230-251. doi: 10.1111/1467-9248.12040.

Schmidt-Catran, Alexander W., and Romana Careja. 2017. "Institutions, culture and migrants' preference for state-provided welfare. Longitudinal evidence from Germany." Journal of European Social Policy 27 (2):197-212. doi: $10.1177 / 0958928716681463$.

Schmitt, Michael T., and Nyla R. Branscombe. 2002. "The Meaning and Consequences of Perceived Discrimination in Disadvantaged and Privileged Social Groups." European Review of Social Psychology 12 (1):167-199. doi: 10.1080/14792772143000058.

Schoonvaere, Quentin. 2013. Demografische studie over de populatie van Turkse herkomst in België.: Centre de recherche en démographie et sociétés (Demo, UCL) \& Centrum voor gelijkheid van kansen en voor racismebestrijding.

Schoonvaere, Quentin. 2014. België-Marokko: 50 jaar migratie. Demografische studie over de populatie van Marokkaanse herkomst in België.: Centre de recherche en démographie et sociétés. Federaal Centrum voor de analyse van de migratiestromen, de bescherming van de grondrechten van de vreemdelingen en de strijd tegen mensenhandel.

Sears, David O., Richard R. Lau, Tom R. Tyler, and Harris M. Allen, Jr. 1980. "Self-Interest vs. Symbolic Politics in Policy Attitudes and Presidential Voting." American Political Science Review 74 (3):670-684. doi: 10.2307/1958149.

Smith, Heather J., and D.J. Ortiz. 2002. "Is it just me? The different consequences of personal and group relative deprivation." In Relative deprivation : specification, development, and integration, edited by Iain Walker and Heather J. Smith, 91-115. Cambridge: Cambridge University press.

Smith, Heather J., Thomas F. Pettigrew, Gina M. Pippin, and Silvana Bialosiewicz. 2012. "Relative Deprivation: A Theoretical and Meta-Analytic Review." Personality and Social Psychology Review 16 (3):203-232. doi: 10.1177/1088868311430825. 
Staerklé, Christian, Tiina Likki, and Régis Scheidegger. 2012. "A Normative Approach to Welfare Attitudes." In Contested Welfare States. Welfare attitudes in Europe and beyond., edited by Stefan Svallfors, 73-100. Stanford, California: Stanford Press.

Stegmueller, Daniel, Peer Scheepers, Sigrid Roßteutscher, and Eelke de Jong. 2012. "Support for Redistribution in Western Europe: Assessing the role of religion." European Sociological Review 28 (4):482-497. doi: 10.1093/esr/jcr011.

Stouffer, Samuel A, Edward A Suchman, Leland C DeVinney, Shirley A Star, and Robin M Williams Jr. 1949. The American soldier: adjustment during army life. Vol. 1, Studies in social psychology in World War II. Princeton (N.J.): Princeton University Press.

Surkyn, Johan, and Georges Reniers. 1996. "Selecte gezelschappen. Over de migratiegeschiedenis en de interne dynamiek van migratieprocessen." In Diversiteit in sociale verandering: Turkse en Marokkaanse vrouwen in België, edited by $\mathrm{R}$. Lesthaeghe, 41-72. Brussel: Centrum voor Bevolkings- en gezinsstudiën.

Svallfors, Stefan. 1995. "The End of Class Politics? Structural Cleavages and Attitudes to Swedish Welfare Policies." Acta Sociologica 38 (1):53-74. doi: 10.2307/4200939.

Svallfors, Stefan. 1997. "Worlds of Welfare and Attitudes to Redistribution: A Comparison of Eight Western Nations." European Sociological Review 13 (3):283-304.

Svallfors, Stefan. 2004. "Class, Attitudes and the Welfare State: Sweden in Comparative Perspective." Social Policy \& Administration 38 (2):119-138. doi: 10.1111/j.14679515.2004.00381.x.

Svallfors, Stefan, ed. 2012. Contested Welfare States. Welfare attitudes in Europe and beyond. Stanford, California: Stanford Press.

Svallfors, Stefan, and Peter Taylor-Gooby, eds. 1999. The end of the welfare state? Responses to state retrenchment. London: Routledge.

Swyngedouw, Marc, Bart Meuleman, Koen Abts, Hassan Bousetta, and Jolien Galle. 2015. Belgian Ethnic Minorities Election Study 2014. Codebook: Questions and Frequency tables. Leuven: ISPO-KU Leuven \& CLEO/CEDEM-Université de Liège.

Teney, Celine, Dirk Jacobs, Andrea Rea, and Pascal Delwit. 2010. "Ethnic voting in Brussels: Voting patterns among ethnic minorities in Brussels (Belgium) during the 2006 local elections." Acta Politica 45 (3):273-297. doi: 10.1057/ap.2009.25.

Timmerman, Christiane, Els Vanderwaeren, and Maurice Crul. 2003. "The Second Generation in Belgium." International Migration Review 37 (4):1065-1090. doi: 10.1111/j.1747-7379.2003.tb00170.x.

Timonen, Virpi, and Martha Doyle. 2009. "In Search of Security: Migrant Workers' Understandings, Experiences and Expectations Regarding 'Social Protection' in Ireland." Journal of Social Policy 38 (1):157-175. doi: 10.1017/S0047279408002602.

Torrekens, Corinne, and Ilke Adam. 2015. Marokkaanse en Turkse Belgen : een (zelf)portret van onze medeburgers. Brussel: Koning Boudewijnstichting. 
Van den Broucke, Sarah, Jo Noppe, Karen Stuyck, Philippe Buysschaert, Gerlinde Doyen, and Johan Wets. 2015. Vlaamse Migratie- en Integratiemonitor 2015.

Antwerpen/Brussel: Steunpunt Inburgering en Integratie/Agentschap Binnenlands Bestuur.

Van der Waal, Jeroen, Willem De Koster, and Wim Van Oorschot. 2013. "Three Worlds of Welfare Chauvinism? How Welfare Regimes Affect Support for Distributing Welfare to Immigrants in Europe." Journal of Comparative Policy Analysis: Research and Practice 15 (2):164-181. doi: 10.1080/13876988.2013.785147.

van Oorschot, Wim. 2000. "Who should get what, and why? On deservingness criteria and the conditionality of solidarity among the public." Policy \& Politics 28 (1):33-48. doi: $10.1332 / 0305573002500811$.

van Oorschot, Wim. 2006. "Making the difference in social Europe: deservingness perceptions among citizens of European welfare states." Journal of European Social Policy 16 (1):23-42. doi: 10.1177/0958928706059829.

van Oorschot, Wim. 2010. "Public perceptions of the economic, moral, social and migration consequences of the welfare state: an empirical analysis of welfare state legitimacy." Journal of European Social Policy 20 (1):19-31. doi: 10.1177/0958928709352538.

Van Robaeys, Bea, and Nathalie Perrin. 2007. De kleur van armoede. Amoede bij personen van buitenlandse herkomst. Edited by Boudewijnstichting Koning, OaseS, Centre d'Etudes de l'Ethnicité et des Migrations. Leuven: Acco.

van Tubergen, Frank. 2007. "Religious Affiliation and Participation among Immigrants in a Secular Society: A Study of Immigrants in The Netherlands." Journal of Ethnic and Migration Studies 33 (5):747-765. doi: 10.1080/13691830701359181.

Van Zomeren, Martijn, Tom Postmes, and Russell Spears. 2008. "Toward an integrative social identity model of collective action: a quantitative research synthesis of three socio-psychological perspectives." Psychological bulletin 134 (4):504-535.

Vanneman, Reeve D., and Thomas F. Pettigrew. 1972. "Race and Relative Deprivation in the Urban United States." Race \& Class 13 (4):461-486. doi: 10.1177/030639687201300404.

Verkuyten, Maykel. 1998. "Perceived Discrimination and Self-Esteem Among Ethnic Minority Adolescents." The Journal of Social Psychology 138 (4):479-493. doi: 10.1080/00224549809600402.

Verkuyten, Maykel. 2005. The social psychology of ethnic identity: Psychology Press.

Verkuyten, Maykel. 2008. "Life Satisfaction among Ethnic Minorities: The Role of Discrimination and Group Identification." Social Indicators Research 89 (3):391404.

Verkuyten, Maykel, and Shervin Nekuee. 1999. "Subjective Well-Being, Discrimination and Cultural Conflict: Iranians Living in The Netherlands." Social Indicators Research 47 (3):281-306. doi: 10.1023/a:1006970410593. 
Walker, Iain, and Heather J. Smith. 2002. Relative deprivation : specification, development, and integration. Edited by Iain Walker and Heather J. Smith. Cambridge: Cambridge University press.

Wright, Matthew, and Tim Reeskens. 2013. "Of what cloth are the ties that bind? National identity and support for the welfare state across 29 European countries." Journal of European Public Policy 20 (10):1443-1463. doi: 10.1080/13501763.2013.800796. 
Table 1. Descriptive statistics of attitudes toward government responsibility and redistribution, economic insecurity and perceived group discrimination for Belgians of Turkish and Moroccan descent

\begin{tabular}{|c|c|c|c|c|c|c|c|c|}
\hline Latent concept & Survey items & Scale & Mean & $\begin{array}{l}\text { Std. } \\
\text { dev. }\end{array}$ & $\%$ min. & $\% \max$. & $\mathbf{N}$ & $\begin{array}{l}\text { Std. } \\
\text { factor } \\
\text { loading }\end{array}$ \\
\hline \multirow{3}{*}{$\begin{array}{l}\text { Attitude toward } \\
\text { redistribution }\end{array}$} & $\begin{array}{l}\text { The differences between classes ought to } \\
\text { be smaller than they are now. }\end{array}$ & \multirow{3}{*}{$\begin{array}{l}\text { 1: completely } \\
\text { disagree }-5: \\
\text { completely agree }\end{array}$} & 3.99 & 1.02 & 2.66 & 34.81 & 790 & 0.764 \\
\hline & $\begin{array}{l}\text { The differences between high and low } \\
\text { incomes should stay as they are. }\end{array}$ & & 2.22 & 0.99 & 22.6 & 1.89 & 792 & -0.543 \\
\hline & $\begin{array}{l}\text { The government should reduce income } \\
\text { differentials. }\end{array}$ & & 3.77 & 1.02 & 2.41 & 23.7 & 789 & 0.692 \\
\hline \multirow{3}{*}{$\begin{array}{l}\text { Attitude toward } \\
\text { government } \\
\text { responsibility }\end{array}$} & $\begin{array}{l}\text { To what extent do you think that the } \\
\text { government should be responsible for this } \\
\text { or not: For making sure the elderly have a } \\
\text { reasonable pension. }\end{array}$ & \multirow{3}{*}{$\begin{array}{l}\text { 0: government has } \\
\text { no responsibility - } \\
\text { 10: government has } \\
\text { all the } \\
\text { responsibility }\end{array}$} & 8.75 & 1.67 & 0.5 & 45.67 & 797 & 0.702 \\
\hline & $\begin{array}{l}\text { To what extent do you think that the } \\
\text { government should be responsible for this } \\
\text { or not: For making sure there is affordable } \\
\text { health care for all. }\end{array}$ & & 9.03 & 1.48 & 0.25 & 54.83 & 797 & 0.693 \\
\hline & $\begin{array}{l}\text { To what extent do you think that the } \\
\text { government should be responsible for this } \\
\text { or not: For making sure that the } \\
\text { unemployed have a reasonable standard of } \\
\text { living. }\end{array}$ & & 7.71 & 2.2 & 1.64 & 28.12 & 793 & 0.658 \\
\hline $\begin{array}{l}\text { Perceived group } \\
\text { discrimination }\end{array}$ & $\begin{array}{l}\text { If we need something from the } \\
\text { government, people like me have to wait } \\
\text { longer than others. }\end{array}$ & $\begin{array}{l}\text { 1: completely } \\
\text { disagree }-5: \\
\text { completely agree }\end{array}$ & 2.95 & 1.05 & 4.99 & 5.38 & 781 & 0.761 \\
\hline
\end{tabular}




\begin{tabular}{|c|c|c|c|c|c|c|c|c|}
\hline & $\begin{array}{l}\text { People like me are being systematically } \\
\text { neglected, whereas other groups receive } \\
\text { more than they deserve. }\end{array}$ & & 3.05 & 1.03 & 4.83 & 5.22 & 786 & 0.874 \\
\hline & $\begin{array}{l}\text { In times of economic crisis, people like me } \\
\text { are always the first victims. }\end{array}$ & & 3.12 & 1.06 & 3.93 & 7.99 & 788 & 0.708 \\
\hline & $\begin{array}{l}\text { At the social assistance agency } \\
\text { (OCMW/CPAS) and the city services, they } \\
\text { view people of my descent as a burden. }\end{array}$ & & 3 & 0.96 & 4.45 & 3.78 & 741 & 0.518 \\
\hline \multirow{3}{*}{ Economic insecurity } & $\begin{array}{l}\text { Are you sometimes worried about one of } \\
\text { the following things?: That your financial } \\
\text { worries will increase in the coming years? }\end{array}$ & \multirow{3}{*}{ 1: never - 5: often } & 3.48 & 1.18 & 8.48 & 19.75 & 790 & 0.821 \\
\hline & $\begin{array}{l}\text { Are you sometimes worried about one of } \\
\text { the following things?: That you will have } \\
\text { difficulties to keep your socio-economic } \\
\text { position? }\end{array}$ & & 3.17 & 1.17 & 9.87 & 15.57 & 790 & 0.905 \\
\hline & $\begin{array}{l}\text { Are you sometimes worried about one of } \\
\text { the following things?: That your children } \\
\text { and the coming generation will have it } \\
\text { much more difficult? }\end{array}$ & & 3.78 & 1.22 & 7.89 & 34.73 & 786 & 0.745 \\
\hline
\end{tabular}

Source: Belgian Ethnic Minorities Election Study (BEMES) 2014.

The measurement equivalence of the model across the two ethnic group was tested, and goodness-of-fit indices (available on request) showed that full scalar equivalence was obtained. 

Table 2. Fully standardized effect parameters (and p-values) of model explaining attitudes toward government responsibility and redistribution

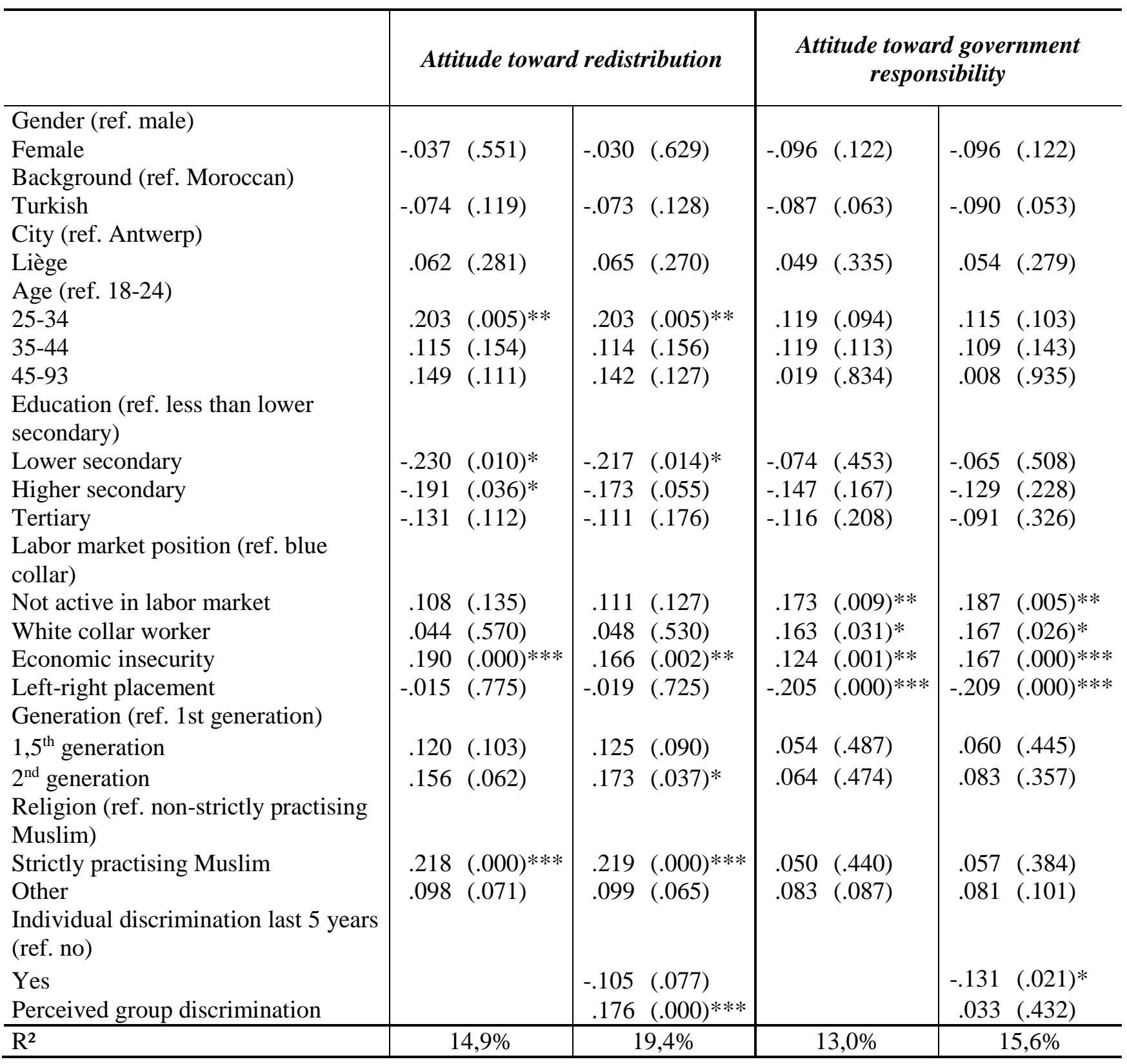

Source: Belgian Ethnic Minorities Election Study (BEMES) 2014; N = 799; * p<.05 ** $\mathrm{p}<.01 * * * \mathrm{p}<.001$ 
Table Appendix. Descriptive statistics of the observed variables, BEMES 2014

\begin{tabular}{|c|c|}
\hline Variable and categories & \% or mean (S.D.) \\
\hline \multicolumn{2}{|l|}{ Gender } \\
\hline Male & $50.4 \%$ \\
\hline Female & $49.6 \%$ \\
\hline \multicolumn{2}{|l|}{ Background } \\
\hline Moroccan & $49.3 \%$ \\
\hline Turkish & $50.7 \%$ \\
\hline \multicolumn{2}{|l|}{ City } \\
\hline Antwerp & $57.1 \%$ \\
\hline Liège & $42.9 \%$ \\
\hline \multicolumn{2}{|l|}{ Age } \\
\hline $18-24$ & $31.8 \%$ \\
\hline $25-34$ & $28.2 \%$ \\
\hline $35-44$ & $23.8 \%$ \\
\hline $45-93$ & $16.3 \%$ \\
\hline \multicolumn{2}{|l|}{ Education } \\
\hline Less than secondary education & $8.8 \%$ \\
\hline Lower secondary & $25.7 \%$ \\
\hline Higher secondary & $47.9 \%$ \\
\hline Tertiary & $17.7 \%$ \\
\hline \multicolumn{2}{|l|}{ Labor market position } \\
\hline Blue collar worker & $20.8 \%$ \\
\hline Not active in labor market & $52.2 \%$ \\
\hline White collar worker & $27.0 \%$ \\
\hline Left-right placement & $3.99(2.36)$ \\
\hline \multicolumn{2}{|l|}{ Generation } \\
\hline $1^{\text {st }}$ generation & $16.5 \%$ \\
\hline $1,5^{\text {th }}$ generation & $20.7 \%$ \\
\hline $2^{\text {nd }}$ generation & $62.8 \%$ \\
\hline \multicolumn{2}{|l|}{ Religion } \\
\hline Non-strictly practising Muslim & $47.3 \%$ \\
\hline Strictly practising Muslim & $39.8 \%$ \\
\hline Other & $12.9 \%$ \\
\hline \multicolumn{2}{|l|}{$\begin{array}{l}\text { Discriminated against last } 5 \\
\text { years }\end{array}$} \\
\hline No & $50.9 \%$ \\
\hline Yes & $49.1 \%$ \\
\hline
\end{tabular}

